\title{
Leczenie farmakologiczne napadów migotania przedsionków
}

\section{Efficacy of pharmacological treatment in episodes of paroxysmal atrial fibrillation}

\author{
Anna Jankiewicz-Błoch ${ }^{1}$, Jacek Zawadzki ${ }^{2}$, Wojciech Kustrzycki ${ }^{3}$, Agnieszka Sławuta ${ }^{4}$ \\ ${ }^{1}$ Oddział Chorób Wewnętrznych z Pododdziałem Gastroenterologicznym, ZOZ w Oławie \\ ${ }^{2}$ Studenckie Koło Naukowe, Zakład Pielęgniarstwa Internistycznego, Uniwersytet Medyczny we Wrocławiu \\ ${ }^{3}$ Zakład Pielęgniarstwa Internistycznego, Uniwersytet Medyczny we Wrocławiu \\ ${ }^{4}$ Oddział Kardiologii, Szpital ZOZ w Kłodzku
}

\section{Streszczenie}

Migotanie przedsionków jest najczęściej występującą arytmią nadkomorową na świecie. Wśród najpopularniejszych schematów farmakoterapii nieutrwalonych epizodów migotania przedsionków wyróżnia się kontrolę częstości rytmu serca, jak i kontrolę częstości rytmu komór. Leki antyarytmiczne można klasyfikować zarówno na podstawie ich profilu działania, jak też szczególnych wskazań do zastosowania. W dobieraniu odpowiedniego sposobu leczenia zwraca się uwagę na liczne czynniki zależne od pacjenta, w tym schorzenia wspótistniejące i obecność strukturalnej choroby serca. Dostępność leków antyarytmicznych w Polsce jest dość ograniczona. Niestety, nie istnieją uniwersalne schematy lekowe, które gwarantują najlepszą skuteczność i bezpieczeństwo terapii. Niniejszy artykuł przedstawia opis działania, profil farmakokinetyczny i ocenę skuteczności, potwierdzoną w badaniach naukowych, najczęściej używanych leków dostępnych w Polsce w leczeniu epizodów nieutrwalonego migotania przedsionków.

Słowa kluczowe: migotanie przedsionków, skuteczność leków antyarytmicznych, leki antyarytmiczne

Folia Cardiologica 2018; 13, 4: 331-337

\section{Wstęp}

Pomimo postępów w diagnostyce i leczeniu migotania przedsionków (AF, atrial fibrillation) pozostaje ono nadal najczęstszą arytmią nadkomorową. Cechuje ją szybka (powyżej 300-350 pobudzeń/min) nieskoordynowana aktywacja przedsionków, której towarzyszy niemiarowy rytm komór (poza przypadkami całkowitego bloku przewodzenia przedsionkowo-komorowego), co doprowadza do utraty efektywności hemodynamicznej skurczu mięśnia sercowego (ok. 15-30\% w zależności od towarzyszących schorzeń) [1, 2]. Obecnie szacuje się, że około 3\% populacji ogólnej w wieku > 19 roku życia choruje z powodu migotania przedsionków, częściej mężczyźni niż kobiety. W 2010 roku oszacowano liczbę przypadków AF na świecie na około 20,9 mln u mężczyzn i 12,6 mln u kobiet [3, 4]. Wśród chorujących przeważają osoby starsze, z dodatkowymi schorzeniami kardiologicznymi jak i niekardiologicznymi $[1,3]$. Należy pamiętać, iż migotanie przedsionków jest niezależnie związane ze zwiększoną umieralnością [5].

\section{Etiologia migotania przedsionków}

Etiologia zjawiska jest złożona. Wśród stanów chorobowych, które zwiększają ryzyko arytmii możemy wyróżnić związane bezpośrednio z układem sercowo-naczyniowymi - nadciśnienie tętnicze, choroba niedokrwienna serca, wady zastawkowe nabyte i wrodzone (głównie wady zastawki

Adres do korespondencji: Jacek Zawadzki, Studenckie Koło Naukowe, Zakład Pielęgniarstwa Internistycznego, Uniwersytet Medyczny we Wrocławiu, ul. Bartla 5, 51-618 Wrocław, e-mail: jacekzawadzkimed@gmail.com 
mitralnej) oraz pozasercowe - nadczynność tarczycy, ostre zakażenia, znieczulenie ogólne, choroby płuc, obturacyjny bezdech senny [1, 3]. Jeśli AF ma początek we wczesnym wieku, możemy z dużym prawdopodobieństwem oprzeć jego przyczynę na komponencie dziedzicznym [6]. Około 1/3 pacjentów z AF mogą być nosicielami mutacji genetycznych sprzyjających występowaniu arytmii [7].

Wśród mechanizmów patofizjologicznych możemy wyróżnić przebudowę strukturalną, jak również zaburzenia elektrofizjologiczne, w tym zmiany ogniskowej aktywności w okolicy żył płucnych, rzadziej zatoce wieńcowej czy żyle głównej górnej, które zaburzając jednolitą aktywację przedsionków prowadzą do arytmii. Mechanizmem tej ogniskowej aktywności może być zarówno aktywność wyzwalana (ektopia) jak i zjawisko fal reentry [8, 9].

\section{Klinika i rozpoznanie AF}

Objawy kliniczne migotania przedsionków mogą być zróżnicowane i zależą przede wszystkim od kwestii osobniczej, ale także od sprawności przewodzenia arytmii do komór, ich kurczliwości i chorób współistniejących.

Rozpoznanie migotania przedsionków opiera się przede wszystkim o zarejestrowany w EKG (spoczynkowym, wysiłkowym lub holterowskim) typowy obraz AF - niemiarowość zupełna pomiędzy odstępami R-R oraz brak załamka $\mathrm{P}$, który zastąpiony jest falą f (o różnym napięciu).

W zależności od czasu trwania, samoograniczenia się napadu i objawów klinicznych migotanie przedsionków możemy podzielić na 5 typów [2]:

- AF rozpoznane po raz pierwszy,

- napadowe AF - ustępuje najczęściej do 48 h lub została poddana kardiowersji elektrycznej do $7 \mathrm{dni}$,

- przetrwale AF - trwa dłużej niż 7 dni, włącznie z epizodami poddanymi $\mathrm{KE}$,

- długotrwale przetrwałe AF - trwa rok lub więcej, jeśli wybrano strategię kontroli rytmu,

- utrwalone AF - arytmia, która została zaakceptowana przez pacjenta i lekarza, zrezygnowano ze strategii kontroli rytmu serca.

\section{Farmakoterapia napadów AF}

Profilaktykę wtórną migotania przedsionków, czyli odpowiedni dobór leków antyarytmicznych redukujących częstość napadów AF, możemy opierać na preparatach z różnych grup farmakologicznych [2]. Najpowszechniejszy podział leków według Vaughan-Williams opiera się na elektrofizjologicznym mechanizmie ich działania [10]. W tabeli przedstawiono jedynie grupy istotne dla niniejszego opracowania (tab. 1). Dostępność leków antyarytmicznych w Polsce jest ograniczona, dlatego w niniejszej części zostaną omówione tylko najpopularniejsze substancje, które stosowane są w epizodach napadów AF.

Odpowiedź na pytanie: które leki są najskuteczniejsze, a jednocześnie najbezpieczniejsze w terapii chorych z nieutrwalonym migotaniem przedsionków, jest trudna. Skuteczność większości leków antyarytmicznych nie przekracza $50 \%$, a ponadto każdy z nich posiada potencjał proarytmiczny. Dodatkowo w krótkotrwałych napadach AF można liczyć się z 25-50\% spontaniczną konwersją [11]. Liczne publikacje opisują pojedyncze substancje oraz podejmują próby oceny skuteczności leczenia antyarytmicznego. Jedna z metaanaliz z 2006 roku obejmowała 44 badania, w których oceniano skuteczność leczenia antyarytmicznego, tolerancję i bezpieczeństwo głównych leków antyarytmicznych w migotaniu przedsionków, takich jak: amiodaron, sotalol, dronedaron, flekainid i propafenon w porównaniu do placebo. We wnioskach z metaanalizy stwierdzono największy potencjał antyarytmiczny w nawrotach migotania przedsionków dla amiodaronu (OR 0,22, 95\% Cl 0,16-0,29), ale także, obok sotalolu, ich zwiększony wpływ na śmiertelność (dla amiodaronu OR 2,17, 95\% Cl 0,63-7,51; dla sotalolu OR 3,44, 95\% Cl 1,02-11,59) [12].

Widać więc, iż optymalny dobór farmakoterapii w migotaniu przedsionków może stać się nie lada wyzwaniem. Zawarte poniżej informacje odnoszą się do leczenia napadów migotania przedsionków.

\section{Klasa Ic}

\section{Propafenon}

Propafenon jest lekiem wykazującym działanie blokujące kanały sodowe, stabilizującym błony komórkowe, o słabym działaniu beta-adrenolitycznym. Propafenon stosowany jest w przypadku AF o niedawnym początku, u osób bez strukturalnej choroby serca.

Ocena skuteczności i bezpieczeństwa propafenonu i sotalolu vs placebo u chorych z nawracającym i objawowym

Tabela 1. Podział leków antyarytmicznych według Vaughan-Williams (zmodyfikowany).

$\begin{array}{lll}\text { Klasa } & \text { Mechanizm działania } & \text { Przykłady preparatów } \\ \text { IC } & \text { Blokery kanałów sodowych } & \text { propafenon, flekainid, enkainid } \\ \text { II } & \text { Blokery receptorów beta-adrenergicznych } & \text { propranolol, esmolol, metoprolol, atenolol } \\ \text { III } & \text { Blokery kanałów potasowych } & \text { amiodaron, dronedaron, sotalol, ibutylid, dofetylid, vernakalant } \\ \text { V } & \text { Inne mechanizmy działania } & \text { fenazolina }\end{array}$


AF w utrzymaniu rytmu zatokowego wykazała, iż oba leki są podobne w skuteczności utrzymania rytmu zatokowego, a jednocześnie opóźniają czas do wystąpienia nawrotów AF jak i zmniejszają ich objawowość [13].

W badaniu Alboniego i wsp. oceniano skuteczność flekainindu i propafenonu w schemacie pill in the pocket. Do badania włączono chorych z napadami migotania przedsionków o niedawnym początku i dość dobrą tolerancja arytmii. Okazało się, że u $84 \%$ chorych podawanie leku w ramach pigułki w kieszeni było skuteczne i bezpieczne oraz zmniejszyło znacznie incydenty hospitalizacji z powodu arytmii [14]. Skuteczność podania dożylnego propafenonu oceniana w badaniu Fak i wsp. w grupie osób w krótkotrwałym napadem AF wynosiła $65 \%$ i była wyraźnie wyższa od grupy placebo (8\%) w czasie 60 minut od interwencji [15].

W podsumowaniu można stwierdzić, iż skuteczność propafenonu jest stosunkowo wysoka - ok. 60-70\% w przypadku pacjentów z napadowym migotaniem przedsionków o niedawnym początku. Dzięki swojemu profilowi farmakokinetycznemu jest skuteczny jako lek podręczny do przerywania napadu AF w warunkach pozaszpitalnych. Według zaleceń ESC z 2016 roku dotyczących leczenia napadowego migotania przedsionków, propafenon zalecany jest w pierwszej linii obok flekainidu, jednak jego użycie jest ograniczone do pacjentów bez strukturalnej choroby serca [2]. Terapia pill in the pocket - dawka doustna 150-600 mg. Ta ostatnia raczej u osób nie stosujących leku przewlekle.

\section{Flekainid}

Mechanizm działania tego leku polega blokowaniu kanałów sodowych oraz zmniejszaniu komórkowej kumulacji jonów wapniowych. Ten ostatni mechanizm redukuje procesy stresu oksydacyjnego i zapobiega remodelingowi przedsionków [16].

Randomizowane badania kliniczne porównywały flekainid z innymi antyarytmikami w przerywaniu napadów migotania przedsionków. Capucci i wsp. wykazali, że pojedyncza aplikacja doustnej dawki nasycającej flekainidu okazała się bardziej efektywna niż dożylne podanie propafenonu w ciągu 8 godzin obserwacji. Ten szybki efekt nie utrzymywał się jednak w okresie 24 godzin [17]. Do podobnych wniosków doszli Martínez-Marcos i wsp., udowadniając, że wyraźnie większa liczba pacjentów uzyskała rytm zatokowy, będąc leczona dożyInie stosowanym flekainidem, w porównaniu do amiodaronu lub propafenonu [18]. Romano i wsp. podobnie wykazali większą skuteczność dożylnego flekainidu w ustąpieniu nagłego nawrotu migotania przedsionków w pierwszej, trzeciej i szóstej godzinie po podaniu leku w porównaniu do amiodaronu lub propafenonu. Różnica ta zatarła się po 24 godzinach [19]. Boriani i wsp. ocenili skuteczność przywracania rytmu zatokowego i doszli do wniosku, iż doustnie podawany flekainid ma podobną skuteczność w porównaniu z doustnie podawanym propafenonem [20].

Flekainid staje się coraz bardziej popularny w Polsce, jednak problemem jest jego dostępność. Według zaleceń ESC zalecany jest w pierwszej linii obok propafenonu, jednak jego użycie może być ograniczone tylko do pacjentów bez strukturalnej choroby serca.

Terapia pill in the pocket - bolus 200-300 mg [2].

\section{Klasa II}

Jest to grupa leków, która wykazuje główne działanie antagonistyczne działanie w stosunku do receptorów beta-adrenergicznych. Wśród efektów biologicznego działania leków tej grupy w obrębie serca należy wymienić działanie chronotropowe, inotropowe, dromotropowe i lusitropowe ujemne, co poprawia znacznie metabolizm samego mięśnia sercowego i przepływ wieńcowy [21].

Choć w większości przypadków podanie dożylne beta-blokera - gównie metoprololu - znajduje sie w schemacie leczenia u chorych z napadem migotanie przedsionków, to jednak nie ma obecnie żadnego badania, które wskazywałoby na skuteczność p/arytmiczną leku. Być może wynika to z faktu, że w ciągu 48 godzin ustępuje zwykle 25 do 50\% napadów [11], jednak nie ma badania porównawczego z placebo co do komponentu antyarytmicznego, poza zwolnieniem przewodzenia w łączu przedsionkowo-komorowym i zwolnieniem rytmu komór. W Polsce jako dożylne formy leku dostępne są metoprolol i propranolol. Według zaleceń ESC, beta-blokery nie stanowią skutecznego leku w leczeniu napadowego migotania przedsionków [2].

\section{Klasa III}

\section{Sotalol}

Sotalol jest lekiem wydłużającym czas trwania potencjału czynnościowego i okresu refrakcji komórek miokardium poprzez wpływ na kanały potasowe. Z uwagi na właściwości, wywołuje efekt chrono- i inotropowo ujemny, a także hipotensyjny, zmniejsza też zapotrzebowanie serca na tlen. Typowe zmiany w EKG po zastosowaniu odpowiednich dawek sotalolu to wydłużenie odstępu PQ oraz QT, a także zwolnienie rytmu serca [1].

Próby oceny skuteczności sotalolu jako leku antyarytmicznego u pacjentów z migotaniem przedsionków podejmowano w wielu pracach. W badaniu Reimolda porównano działanie propafenonu oraz sotalolu u chorych z nawracającymi epizodami AF. Okazało się, iż sotalol jak i propafenon posiadały podobną skuteczność w utrzymaniu rytmu zatokowego u chorych po kardiowersji elektrycznej z powodu epizodów migotania przedsionków (napadowych jak i przetrwałych) w rocznej obserwacji [22]. Kolejną próbą porównania skuteczności, tym razem leków z tej samej grupy było badanie SAFE-T, w którym 
podjęto próbę oceny amiodaronu i sotalolu pod względem ich skuteczności w przywracaniu jak i utrzymaniu rytmu zatokowego u chorych z nawracającym AF. Chorych podzielono na trzy grupy (I - amiodaron, II - sotalol, III - placebo). Okazało się, iż amiodaron, jak też sotalol, wykazywały podobną skuteczność w konwersji AF, z kolei amiodaron wykazywał korzystniejszy wpływ na utrzymanie rytmu zatokowego [23].

Porównanie skuteczności stosowanego dożylnie sotalolu i flekainidu wypada na niekorzyść tego pierwszego. W grupie 106 chorych z krótkotrwałym napadem AF sotalol powodował konwersje do rytmu zatokowego jedynie u $23 \%$ chorych, a w grupie flekainidu u $53 \%$ w ciągu 2 godzin od podania leków [24].

Widać więc, że sotalol, pomimo zaliczania go do grupy starszych leków antyarytmicznych, wykazuje zadowalająca skuteczność w konwersji AF do rytmu zatokowego. Należy jednak pamiętać o znaczącym działaniu proarytmicznym, zwłaszcza o ryzyku arytmii komorowej typu torsade de pointes. Według zaleceń ESC sotalol jest zalecany do leczenia napadowego migotania przedsionków, jednak jego skuteczność w przywracaniu rytmu zatokowego określana jest jako niższa w porównaniu do amiodaronu i flekainidu [2].

\section{Amiodaron}

Amiodaron jest jodową pochodną benzofuranu. Jego główne działanie jest złożone, opiera się o hamujący wpływ na kanały potasowe, co skutkuje wydłużeniem okresu repolaryzacji oraz refrakcji wszystkich komórek mięśnia sercowego. Hamuje ponadto kanały sodowe i niekompetytywnie, blokuje receptory beta-adrenenrgiczne, a także osłabia czynność kanałów wapniowych typu L. Choć lek wykazuje słabe działanie proarytmiczne, może jednak znacząco wydłużać odstęp QT w EKG.

Skuteczność amiodaronu oceniano w licznych badaniach i metaanalizach, zarówno w przetrwałym jak i napadowym migotaniu przedsionków. Jednym ze starszych, z 1998 roku, było randomizowane badanie Kochiadakisa i wsp., w którym porównywano niskie dawki amiodaronu w celu zahamowania nawrotów AF u pacjentów objawowych. Porównanie to prowadzono w stosunku do sotalolu. W badaniu wzięło udział 70 chorych, których podzielono na pół: 35 jako grupę amiodaronu i 35 jako grupę sotalolu. Wyłączono z badania pacjentów z niską frakcją wyrzutową lewej komory < $40 \%$ oraz z klinicznie istotną choroba serca. Wnioski były następujące: zarówno sotalol jak i amiodaron mogą być stosowane w celu utrzymania rytmu zatokowego u chorych z nawracającym objawowym AF, ale amiodaron jest skuteczniejszy z tych dwóch leków (10 z 35 pacjentów z amiodaronem rozwinęła AF w ciągu rocznej obserwacji vs 21 z 35 pacjentów stosujących sotalol) [25].

Stosunkowo współczesne badanie dowiodło dużej skuteczności amiodaronu stosowanego doustnie w celu przerwania krótkotrwałego $(<4 \mathrm{~h})$ napadu AF w grupie
48 osób w wieku 60+/-4 lat. Pojedyncza dawka leku wynosiła 30 mg/kg m.c. Rytm zatokowy uzyskano u 47 chorych w średnim czasie 6 godzin. Nie odnotowano istotnych działań niepożądanych poza złą tolerancją leku u 3 chorych [26].

Wśród różnych metaanaliz, dotyczących skuteczności działania amiodaronu w arytmiach nadkomorowych, należy wspomnieć o pracy Chevalier i wsp., gdzie oceniano skuteczność przywracania rytmu zatokowego u chorych z napadowym migotaniem przedsionków (trwającym nie dłużej niż tydzień) w porównaniu z placebo i lekami antyarytmicznymi grupy Ic. Metaanaliza obejmowała 10 badań z randomizacją przeprowadzonych w latach 1967-2001. Oceniano główny punkt końcowy - powrót rytmu zatokowego w ciągu pierwszych 24 godzin dożylnego leczenia antyarytmicznego. Wnioski z analizy potwierdziły, iż amiodaron jest skuteczniejszy w przywracaniu rytmu zatokowego u pacjentów z napadowym AF w porównaniu z placebo i podobnie skuteczny w porównaniu z lekami grupy Ic, przy czym te ostatnie szybciej prowadziły do osiągnięcia konwersji AF do rytmu zatokowego [27].

Według zaleceń ESC amiodaron jest zalecany do leczenia napadowego migotania przedsionków u pacjentów z niewydolnością serca oraz z chorobą niedokrwienną serca. Należy również pamiętać, że amiodaron zwalnia rytm serca o około 10-12 ud/min zwłaszcza po podaniu dożylnym [2].

\section{Dronedaron}

Dronedaron jest lekiem antyarytmicznym wykazującym właściwości typowe dla wszystkich czterech klas leków według podziału Vaughan-Williams. Według badań dronedaron zapobiega migotaniu przedsionków, przywraca prawidłowy rytm zatokowy, zapobiega częstoskurczom komorowym i migotaniu komór. Mechanizm działania jest związany głównie z blokowaniem kanałów potasowych. Lek hamuje także przepływ sodu i wapnia oraz w sposób niekompetycyjny przeciwdziała aktywacji receptorów adrenergicznych. Nie wywiera wyraźnego wpływu na odstęp QTc lub wydłuża go w niewielkim stopniu.

Obecnie zastosowanie dronedaronu jest ograniczone do postaci doustnej i nie ma pojedynczego badania wskazującego na jego działanie przywracające rytm zatokowy. Według zaleceń ESC dotyczących leczenia napadowego AF, dronedaron nie znalazł miejsca wśród leków odpowiednich dla tego postępowania $[2,28]$.

\section{Antazolina (Phenazolinum)}

Antazolina jest lekiem przeciwhistaminowym I generacji. Wykazuje również działanie cholinolityczne, miejscowo znieczulające i antyarytmiczne podobne do chinidyny. Antazolina stosowana bywa w leczeniu napadów AF. Po podaniu dożylnym działanie antyarytmiczne rozpoczyna się prawie natychmiast. 
W badaniu Farkowskiego i wsp. porównano efektywność i bezpieczeństwo strategii leczenia opartej na antazolinie oraz propafenonie w przypadku krótkotrwałych napadów AF. Przeprowadzono retrospektywną analizę pacjentów poddawanych kardiowersji farmakologicznej przy użyciu dożylnej antazoliny lub propafenonu w latach 2008-2012. Antazolinę użyto 334 razy, z czego w 239 przypadkach okazała się ona skuteczna, co daje 71,6\% skuteczności w porównaniu do propafenonu - 55.1\%. Hospitalizacje były rzadkie i porównywalne dla obu preparatów. Wyniki badania wskazują, że strategia oparta na antazolinie wydaje się efektywniejsza i bezpieczniejsza w stosunku do strategii opartej na propafenonie w przypadku krótkotrwałych AF [29].

Badanie dotyczące antazoliny prowadzili również Balsam i wsp., opisując efektywność antazoliny w przerywaniu napadu AF podczas zabiegu izolacji żył płucnych. Śródzabiegowo napadu mija zwykle w ciągu kilku minut, jednak nie we wszystkich przypadkach. Oceniono 141 pacjentów którzy otrzymali antazolinę dożylnie (max. 500 mg) po okrężnej ablacji ujść żył płucnych. Sukcesem określano przywrócenie rytmu zatokowego w ciągu 20 minut od infuzji. Skuteczność antazoliny określono na 83,6\% w migotaniu napadowym i 31,1\% w przetrwałym [30].

Jednak według najnowszych zaleceń ESC antazolina nie znalazła miejsca wśród leków odpowiednich dla tego postępowania [2].

\section{Vernakalant}

Opisywany jako nowoczesny lek, zaakceptowany do stosowania w UE w 2010 roku. Jego oryginalnym przeznaczeniem jest przywracanie rytmu zatokowego w napadach AF. Mechanizm działania polega na blokowaniu kanałów potasowych. Różnica w stosunku do typowych leków klasy III polega na specyficznym blokowaniu kanałów potasowych I $\mathrm{I}_{\text {to }}$, co zwiększa jego efektywność przy wyższych częstościach rytmu serca [31].

Według badań prowadzonych przez Beatch i wsp. w 2016 r. podawany dożylnie vernakalant skutkował szybkim przywróceniem rytmu zatokowego w przypadku 59 pacjentów, co stanowiło 45,7\% spośród 145 z napadem migotania przedsionków w porównaniu z placebo. W tej ostatniej grupie tylko jeden pacjent powrócił samoczynnie do rytmu zatokowego [32]. W innym badaniu porównano skuteczność vernakalantu i ibutilidu w grupie 100 chorych z krótkotrwałym napadem AF. Zastosowanie vernakalantu skutkowało szybszym (średnio $10 \mathrm{~min}$ ) i częstszym (69 vs $43 \%, p=0,002$ ) przywróceniem rytmu zatokowego [33].

Według zaleceń ESC vernakalant jest wskazany w leczeniu napadowego AF u pacjentów z łagodną niewydolnością serca (NYHA I-II), wliczając pacjentów z chorobą niedokrwienną serca [2]. Lek nie jest dostępny w Polsce.

\section{Podsumowanie}

Migotanie przedsionków jest głównym problemem z zakresu zaburzeń rytmu serca, z którym zetknąć może się każdy lekarz. Z uwagi na starzenie się społeczeństwa należy liczyć sie z rosnącą liczbą przypadków tej arytmii i narastająca falą hospitalizacji. Dlatego bardzo ważne jest współdziałanie systemu ochrony zdrowia i zaangażowanie pacjenta w procesie diagnostyczno-leczniczym, a szczególnie szybkim zwalczaniu napadów arytmii. Nie ma uniwersalnego planu postępowania, a terapia wymaga indywidualizacji w oparciu o istniejące wytyczne, choroby współistniejące u chorego, obecne uszkodzenie serca i doświadczenie lekarza. Armamentarium farmakoterapeutyczne obejmuje antazoline, propafenon, amiodaron, sotalol i flekainid, przy czym dostępność dwóch ostatnich substancji w postaci dożylnej może być ograniczona.

\section{Abstract}

Atrial fibrillation is currently the most common supraventricular arrhythmia in the world, mainly among the elderly with numerous accompanying sicknesses. The strategy also involves patients themselves. Among the most popular schemes of pharmacotherapy in the episodes of atrial fibrillation, the control of heart rate and the control of ventricular heart rate can be distinguished. Antiarrhythmic drugs can be classified, basing on their specific mechanisms of action but also on the indications of their usage. Upon selecting a proper treatment method, the particular attention is paid to numerous factors depending on patients, such as comorbidities and structural heart disease. The availability of antiarrythmics in Poland is relatively limited. Unfortunately, there are no universal drug schemes that would guarantee the best efficiency and safety in the selection of therapy. This article presents the description of action, pharmacokinetic profile, as well as the assessment of efficiency confirmed in scientific research of the most commonly used drugs available in Poland, in the episodes of non-sustained atrial fibrillation.

Keywords: atrial fibrillation, efficacy of antiarrhythmic drugs, antiarrhythmic drugs

Folia Cardiologica 2018; 13, 4: 331-337 


\section{Piśmiennictwo}

1. Gajewski Piotr Interna Szczeklika. Podręcznik chorób wewnętrznych Kraków, Medycyna Praktyczna 2014, rozdz. G 1. ; 7: 237-247.

2. Kirchhof P, Benussi S, Kotecha D, et al. ESC Scientific Document Group. 2016 ESC Guidelines for the management of atrial fibrillation developed in collaboration with EACTS. Eur Heart J. 2016; 37(38): 2893-2962, doi: 10.1093/eurheartj/ehw210, indexed in Pubmed: 27567408.

3. Chugh SS, Havmoeller R, Narayanan K, et al. Worldwide epidemiology of atrial fibrillation: a Global Burden of Disease 2010 Study. Circulation. 2014; 129(8): 837-847, doi: 10.1161/CIRCULATIONAHA.113.005119, indexed in Pubmed: 24345399.

4. Lloyd-Jones DM, Wang TJ, Leip EP, et al. Lifetime risk for development of atrial fibrillation: the Framingham Heart Study. Circulation. 2004; 110(9): 1042-1046, doi: 10.1161/01.CIR.0000140263.20897.42, indexed in Pubmed: 15313941.

5. Benjamin EJ, Wolf PA, D'Agostino RB, et al. Impact of atrial fibrillation on the risk of death: the Framingham Heart Study. Circulation. 1998; 98(10): 946-952, indexed in Pubmed: 9737513.

6. Oyen N, Ranthe MF, Carstensen L, et al. Familial aggregation of lone atrial fibrillation in young persons. J Am Coll Cardiol. 2012; 60(10): $917-$ -921, doi: 10.1016/j.jacc.2012.03.046, indexed in Pubmed: 22726627.

7. Olesen MS, Nielsen MW, Haunsø S, et al. Atrial fibrillation: the role of common and rare genetic variants. Eur J Hum Genet. 2014; 22(3): 297-306, doi: 10.1038/ejhg.2013.139, indexed in Pubmed: 23838598.

8. Haïssaguerre M, Jaïs $P$, Shah DC, et al. Spontaneous initiation of atrial fibrillation by ectopic beats originating in the pulmonary veins. N Engl J Med. 1998; 339(10): 659-666, doi: 10.1056/ /NEJM199809033391003, indexed in Pubmed: 9725923.

9. MOE GK, ABILDSKOV JA. Atrial fibrillation as a self-sustaining arrhythmia independent of focal discharge. Am Heart J. 1959; 58(1): 59-70, indexed in Pubmed: 13661062.

10. Vaughan Williams EM. A classification of antiarrhythmic actions reassessed after a decade of new drugs. J Clin Pharmacol. 1984; 24(4): 129-147, indexed in Pubmed: 6144698.

11. Lip GYH, Apostolakis S, Lip GYH, et al. Atrial fibrillation (acute onset). BMJ Clin Evid. 2011; 2011, indexed in Pubmed: 21718559.

12. Lafuente-Lafuente C, Mouly S, Longás-Tejero MA, et al. Antiarrhythmic drugs for maintaining sinus rhythm after cardioversion of atrial fibrillation: a systematic review of randomized controlled trials. Arch Intern Med. 2006; 166(7): 719-728, doi: 10.1001/archinte.166.7.719, indexed in Pubmed: 16606807.

13. Bellandi F, Simonetti I, Leoncini M, et al. Long-term efficacy and safety of propafenone and sotalol for the maintenance of sinus rhythm after conversion of recurrent symptomatic atrial fibrillation. Am J Cardiol. 2001; 88(6): 640-645, indexed in Pubmed: 11564387.

14. Alboni P, Botto GL, Baldi N, et al. Outpatient treatment of recent-onset atrial fibrillation with the „pill-in-the-pocket” approach. N Engl J Med. 2004; 351(23): 2384-2391, doi: 10.1056/NEJMoa041233, indexed in Pubmed: 15575054.

15. Intravenous Propafenone for Conversion of Atrial Fibrillation or Flutter to Sinus Rhythm: A Randomized, Placebo-controlled, Crossover Study. J Cardiovasc Pharmacol Ther. 1997; 2(4): 251-258, doi: 10.1177/107424849700200403, indexed in Pubmed: 10684466.

16. Andrikopoulos GK, Pastromas S, Tzeis S. Flecainide: Current status and perspectives in arrhythmia management. World J Cardiol.
2015; 7(2): 76-85, doi: 10.4330/wjc.v7.i2.76, indexed in Pubmed: 25717355

17. Alboni P, Botto GL, Boriani G, et al. A double-blind crossover comparison of flecainide and slow-release mexiletine in the treatment of stable premature ventricular complexes. Int J Clin Pharmacol Res. 1991; 11(1): 23-33, indexed in Pubmed: 1714885.

18. Martínez-Marcos FJ, García-Garmendia JL, Ortega-Carpio A, et al. Comparison of intravenous flecainide, propafenone, and amiodarone for conversion of acute atrial fibrillation to sinus rhythm. Am J Cardiol. 2000; 86(9): 950-953, indexed in Pubmed: 11053705.

19. Romano S, Fattore L, Toscano G, et al. [Effectiveness and side effects of the treatment with propafenone and flecainide for recent-onset atrial fibrillation]. Ital Heart J Suppl. 2001; 2(1): 41-45, indexed in Pubmed: 11216083.

20. Boriani G, Biffi M, Capucci A, et al. Conversion of recent-onset atrial fibrillation to sinus rhythm: effects of different drug protocols. Pacing Clin Electrophysiol. 1998; 21(11 Pt 2): 2470-2474, indexed in Pubmed: 9825369.

21. Rienstra M, Damman K, Mulder BA, et al. Beta-blockers and outcome in heart failure and atrial fibrillation: a meta-analysis. JACC Heart Fail. 2013; 1(1): 21-28, doi: 10.1016/j.jchf.2012.09.002, indexed in Pubmed: 24621795.

22. Reimold SC, Cantillon CO, Friedman PL, et al. Propafenone versus sotalol for suppression of recurrent symptomatic atrial fibrillation. Am J Cardiol. 1993; 71(7): 558-563, indexed in Pubmed: 8438741.

23. Singh BN, Singh SN, Reda DJ, et al. Sotalol Amiodarone Atrial FibrilIation Efficacy Trial (SAFE-T) Investigators. Amiodarone versus sotalol for atrial fibrillation. N Engl J Med. 2005; 352(18): 1861-1872, doi: 10.1056/NEJMoa041705, indexed in Pubmed: 15872201.

24. Reisinger J, Gatterer E, Heinze G, et al. Prospective comparison of flecainide versus sotalol for immediate cardioversion of atrial fibrillation. Am J Cardiol. 1998; 81(12): 1450-1454, indexed in Pubmed: 9645896.

25. Kochiadakis G, Igoumenidis N, Marketou M, et al. Low-Dose Amiodarone Versus Sotalol for Suppression of Recurrent Symptomatic Atrial Fibrillation. The American Journal of Cardiology. 1998; 81(8): 995-998, doi: 10.1016/s0002-9149(98)00078-2.

26. Nadarasa K, Williams MJA. Single high oral dose amiodarone for cardioversion of recent onset atrial fibrillation. Heart Lung Circ. 2012; 21(8): 444-448, doi: 10.1016/j.hlc.2012.03.015, indexed in Pubmed: 22554874.

27. Chevalier P, Durand-Dubief A, Burri $\mathrm{H}$, et al. Amiodarone versus placebo and class Ic drugs for cardioversion of recent-onset atrial fibrillation: a meta-analysis. J Am Coll Cardiol. 2003; 41(2): 255-262, indexed in Pubmed: 12535819.

28. Schweizer PA, Becker R, Katus HA, et al. Dronedarone: current evidence for its safety and efficacy in the management of atrial fibrillation. Drug Des Devel Ther. 2011; 5: 27-39, doi: 10.2147/DDDT.S10315, indexed in Pubmed: 21267357.

29. Farkowski MM, Maciąg A, Żurawska M, et al. Comparative effectiveness and safety of antazolinebased and propafenonebased strategies for pharmacological cardioversion of shortduration atrial fibrillation in the emergency department. Pol Arch Med Wewn. 2016; 126(6): $381-$ -387, doi: 10.20452/pamw.3452, indexed in Pubmed: 27362390.

30. Balsam P, Koźluk E, Peller M, et al. Antazoline for termination of atrial fibrillation during the procedure of pulmonary veins isolation. Adv 
Med Sci. 2015; 60(2): 231-235, doi: 10.1016/j.advms.2015.03.002, indexed in Pubmed: 25919055.

31. Finnin M. Vernakalant: A novel agent for the termination of atrial fibrillation. Am J Health Syst Pharm. 2010; 67(14): 1157-1164, doi: 10.2146/ajhp080501, indexed in Pubmed: 20592320.

32. Beatch GN, Mangal B. Safety and efficacy of vernakalant for the conversion of atrial fibrillation to sinus rhythm; a phase $3 \mathrm{~b}$ randomized controlled trial. BMC Cardiovasc Disord. 2016; 16: 113, doi: 10.1186/ /s12872-016-0289-0, indexed in Pubmed: 27233239.

33. Simon A, Niederdoeckl J, Skyllouriotis E, et al. Vernakalant is superior to ibutilide for achieving sinus rhythm in patients with recent-onset atrial fibrillation: a randomized controlled trial at the emergency department. Europace. 2017; 19(2): 233-240, doi: 10.1093/europace/ /euw052, indexed in Pubmed: 28175295. 